Iwan, Ester L. R. Korwa, dan Hengky L. Wambrauw
Peningkatkan Hasil Belajar Peserta Didik Melalui Penerapan Model Pembelajaran Problem Based Learning pada Materi Sistem Pencernaan Manusia Kelas VIII A SMPN 13 Manokwari

\title{
PENINGKATKAN HASIL BELAJAR PESERTA DIDIK MELALUI PENERAPAN MODEL PEMBELAJARAN PROBLEM BASED LEARNING PADA MATERI SISTEM PENCERNAAN MANUSIA DI KELAS VIII A SMPN 13 MANOKWARI
}

\author{
THE INCREASING RESULT OF STUDY WITH PROBLEM BASED \\ LEARNING MODEL APLLIED IN VIII GRADE OF SMPN 13 MANOKWARI \\ STUDENTS
}

\author{
Iwan $^{1}$, Ester L. R. Korwa ${ }^{2}$, Hengky L. Wambrauw ${ }^{3}$ \\ Jurusan Pendidikan Biologi, Fakultas Keguruan dan Ilmu Pendidikan \\ ${ }^{123}$ Universitas Papua \\ Iwan84biounipa@gmail.com ${ }^{1}$
}

\begin{abstract}
This study aims to see students learning outcomes in class VIII A SMPN 13 Manokwari Academic Year 2017/2018 on the Human Digestive System material by applying the model of Problem Based Learning $(P B L)$. Classroom action research (CAR) was conducted in two cycles, each cycle consisting of four stages: 1) planning, 2) implementation, 3) observation, 4) reflection, involving 24 students. Data collection is done through observation sheets, interviews, documentary coverage and tests. The results of this study indicate that the students learning outcomes in Cycle I average 61.3 with $62.5 \%$ completeness and increased to 69.3 with $83.33 \%$ completeness in cycle II. This indicates that the percentage of students learning outcomes have fulfilled standard classical, $75 \%$ of KKM 60. The conclusion show that the learning process with the application of Problem Based Learnig (PBL) model can improve the learning outcomes of students class VIII A SMPN 13 Manokwari .
\end{abstract}

Keywords: Human Digestive System, Learning outcomes, Problem Based Learning (PBL)

\begin{abstract}
Abstrak
Penelitian ini bertujuan untuk melihat hasil belajar peserta didik di kelas VIII A SMPN 13 Manokwari Tahun Ajaran 2017/2018 pada materi Sistem Pencernaan Manusia dengan menerapkan model pembelajaran Problem Based Learning (PBL). Penelitian tindakan kelas (PTK) dilakukan dalam dua siklus, masing-masing siklus terdiri atas empat tahap yaitu, 1)Perencanaan, 2)Pelaksanaan, 3)Pengamatan, 4)Refleksi, yang melibatkan peserta didik sebanyak 24 orang. Pengumpulan data dilakukan melalui lembar observasi, wawancara, peliputan dokumenter dan tes. Hasil penelitian ini menunjukkan bahwa hasil belajar peserta didik pada Siklus I rata-rata 61,3 dengan ketuntasan 62,5\% dan mengalami peningkatan menjadi 69,3 dengan ketuntasan $83,33 \%$ pada siklus II. Hal ini menunjukkan bahwa persentase hasil belajar peserta didik secara klasikal telah memenuhi standar, 75\% dari KKM 60. Berdasarkan hasil penelitian dapat disimpulkan bahwa proses pembelajaran dengan penerapan model Problem Based Learnig (PBL) dapat meningkatkan hasil belajar peserta didik kelas VIII A SMPN 13 Manokwari.
\end{abstract}

Kata kunci: Sistem Pencernaan Manusia, Hasil belajar, Problem Based Learning (PBL)

Jurnal Nalar Pendidikan

Valume 6, Namar 1, Jan-Jun 2018

ISS N : 2339-0749

Halaman [32] 
Iwan, Ester L. R. Korwa, dan Hengky L. Wambrauw
Peningkatkan Hasil Belajar Peserta Didik Melalui Penerapan Model Pembelajaran Problem Based Learning pada Materi Sistem Pencernaan Manusia Kelas VIII A SMPN 13 Manokwari

\section{PENDAHULUAN}

Pembelajaran merupakan kegiatan yang mempunyai tujuan untuk membelajarkan peserta didik agar mencapai kompetensi yang diinginkan. Pembelajaran merupakan suatu hal yang sangat kompleks yang dipengaruhi oleh beberapa faktor antara lain guru, peserta didik, sarana, media, serta lingkungan. Agar pembelajaran berlangsung efektif, guru tidak hanya berfungsi sebagai sumber ilmu, tetapi juga sebagai motivator dan fasilitator dalam pengembangan minat peserta didik dalam mencari ilmu pengetahuan secara mandiri. Kepiawaian guru dalam menumbuhkan minat peserta didik untuk menggali ilmu secara mandiri ini sangat penting dibanding transfer ilmu yang diperoleh murid dari guru secara langsung. Karena itu, bentuk-bentuk pendidikan partisipatif dengan menerapkan metode belajar aktif (active learning) dan belajar bersama (cooperative learning) sangat diperlukan [1].

Berdasarkan hasil wawancara dengan guru mata pelajaran IPA dan hasil observasi selama melaksanakan Program Pengalaman Lapangan (PPL) di SMPN 13 Manokwari dijumpai khususnya pada mata pelajaran IPA guru masih menggunakan metode ceramah, tanya jawab dan memberikan penugasan (pekerjaan rumah) serta 1 dan 2 model pembelajarannya masih bersifat konvesional. Apa yang didapat peserta didik hanya berasal dari guru dan buku saja. Mereka kurang termotivasi untuk belajar secara aktif. Sehingga mereka belum menemukan hal yang menarik dari IPA. Selain itu guru juga jarang menggunakan Media Pembelajaran dalam kegiatan pembelajaran. Hal tersebut dapat menyebabkan rendahnya hasil belajar yang diperoleh peserta didik dan menimbulkan permasalahan yang sering muncul pada peserta didik seperti lemahnya kemampuan peserta didik dalam menggunakan kemampuan berpikirnya untuk menyelesaikan masalah.
Dalam proses kegiatan belajar mengajar (KBM) ditemukan ada peserta didik yang kurang serius dalam mengikut proses pembelajaran, mereka dapat melakukan aktvitas sendiri seperti tidur di kelas pada saat pelajaran sedang berlangsung, bermain handphone (HP), bercerita dengan teman sebangku, bernyanyi, melamun, menggambar di buku catatan, mencoret-coret meja dan kursi, serta meminta izin untuk ke WC dan bermain di luar kelas sampai proses pembelajaran selesai. Selain itu ada terjadinya beberapa pengelompokkan secara individu oleh peserta didik sendiri yaitu antara peserta didik yang mampu dan peserta didik yang kurang mampu sehingga menimbulkan kurangnya kerjasama dalam proses belajar di dalam maupun di luar kelas.

Peserta didik juga merasa kurang tertarik mempelajari mata pelajaran IPA karena menurut mereka sangat susah dan banyak materi yang harus dihafal serta membuat peserta didik menjadi pasif dan kurang berani dalam mengemukakan pendapat, jawaban maupun pertanyaan, serta mengakibatkan hasil belajar yang diperoleh peserta didik kelas VIII A SMPN 13 Manokwari rendah yaitu nilai rata-rata aspek kognitif masih dibawah nilai Kriteria Ketuntasan Minimal (KKM) yaitu 60 dan hal ini belum mencapai ketuntasan klasikal yang ditetapkan oleh pusat yaitu kelas dikatakan tuntas belajar apa bila $75 \%$ peserta didik di kelas tuntas belajar. Hal ini membuktikan bahwa perlu melakukan perubahan dalam pola mengajar dari pembelajaran yang bersifat konvensional ke model pembelajaran tipe kooperatif.

Menurut Ref. [2], untuk merubah kebiasaan praktik pembelajaran dari pembelajaran konvensional ke pembelajaran yang berpusat kepada peserta didik memang tidak mudah, terutama di kalangan guru yang 
Iwan, Ester L. R. Korwa, dan Hengky L. Wambrauw
Peningkatkan Hasil Belajar Peserta Didik Melalui Penerapan Model Pembelajaran Problem Based Learning pada Materi Sistem Pencernaan Manusia Kelas VIII A SMPN 13 Manokwari

tergolong pada kelompok laggard (penolak perubahan/inovasi). Oleh karena itu, solusi yang diberikan menurut peneliti yaitu menerapkan model pembelajaran PBL. Dengan menerapkan model PBL maka dapat memberikan beberapa keuntungan yaitu, dari pembelajaran yang berpusat pada guru (teacher center ed learning) berkurang dan pembelajaran yang berpusat pada peserta didik lebih meningkat (student center ed learning), terjadinya interaksi antara peserta didik dengan guru, peserta didik dan peserta didik dalam membahas topik pembelajaran dalam memecahkan masalah, peserta didik lebih bebas dan berani mengemukakan pendapatnya atau lebih aktif. Dengan alasan dan manfaat yang terdapat dalam model pembelajaran PBL tersebut maka peneliti memilih model PBL untuk meningkatkan hasil belajar peserta didik. Menurut Ref. [3], PBL merupakan salah satu model pembelajaran yang melatih dan mengembangkan kemampuan untuk menyelesaikan masalah yang berorientasi pada masalah autentik dari kehidupan aktual, untuk merangsang kemampuan berpikir tingkat tinggi. Menurut Ref. [4] "pembelajaran berbasis masalah dapat meningkatkan kemampuan berpikir kreatif, karena peserta didik diajak untuk berpikir dan menyelesaikan masalah".

Adapun tujuan dari penerapan Model Pembelajaran PBL yaitu untuk mengetahui peningkatan hasil belajar peserta didik melalui penerapan model pembelajaran Problem Based Learning (PBL) pada materi sistem pencernaan manusia di kelas VIII A SMPN 13 Manokwari.

\section{METODE PENELITIAN}

Menurut Ref. [5], Penelitian ini adalah penelitian tindakan kelas (PTK) dimana peneliti bertindak sebagai pengajar, sedangkan guru mata pelajaran IPA dan teman sejawat bertindak sebagai observer. Model penelitian yang digunakan dalam penelitian ini adalah
Model Kurt Lewin dengan dua siklus yang masing-masing memiliki empat tahapan yaitu, Perencanaan (Planning) dimana peneliti mempersiapkan rencana pelaksanaan pembelajaran (RPP), lembar observasi peserta didik, lembar observasi Guru, kisi-kisi soal, LKPD (lembar kerja peserta didik), Soal, Alat dan bahan yang digunakan. Kemudian tahap Tindakan (Acting) dimana untuk Siklus I dilakukan dalam dua kali pertemuan yaitu untuk pertemuan pertama membahas makanan dan jenis-jenis nutrisi berdasarkan kandungan zat yang ada didalamnya dan mengerjakan LKPD (Lembar Kerja Peserta Didik), untuk pertemuan kedua membahas tentang nutrisi yang terdapat didalam makanan dan vitamin serta fungsi dari bahan makanan. Selanjutnya, Pengamatan (observing) pelaksanaan observasi dilakukan dengan menggunakan instrumen lembar observasi guru dan lembar observasi peserta didik. Terakhir, Refleksi (reflection) Refleksi dilakukan untuk mengetahui hasil akhir dari setiap siklus dan digunakan sebagai dasar apakah sudah memenuhi kriteria atau perlu dilakukan penyempurnaan.

Kriteria keberhasilan tindakan kelas diukur berdasarkan indikator meningkatnya hasil belajar peserta didik. Adapun teknik pengumpulan data menggunakan lembar observasi kegiatan guru, lembar observasi kegiatan peserta didik, dan tes hasil belajar. Analisis data yang diperoleh dari aktivitas dan hasil belajar peserta didik selama mengikuti proses belajar mengajar dan akan dianalisis secara kualitatif yaitu berupa presentase nilai aktivitas dan hasil belajar. Perolehan capaian aktivitas menggunakan rumus :

$$
\% \text { Capaian }=\frac{\text { Jumlah Skor Observer } 1+\text { Observer } 2}{\text { Skor Maksimal }} \times 100
$$


Iwan, Ester L. R. Korwa, dan Hengky L. Wambrauw
Peningkatkan Hasil Belajar Peserta Didik Melalui Penerapan Model Pembelajaran Problem Based Learning pada Materi Sistem Pencernaan Manusia Kelas VIII A SMPN 13 Manokwari
Tabel 1. Kriteria Keberhasilan Belajar

\begin{tabular}{cc}
\hline Rentang Capaian (\%) & Predikat \\
\hline $85-100$ & Sangat baik \\
\hline $70-84$ & Baik \\
\hline $55-69$ & Cukup \\
\hline $40-54$ & Kurang \\
\hline$<40$ & Sangat Kurang
\end{tabular}

Sumber: Ref. [6]

Pemberian skor nilai tes pilihan ganda menurut Ref. [7] adalah sebagai berikut:

$$
\text { Nilai }=\frac{\text { skor } \text { capaian }}{\text { skor maksimal }} \times 100
$$

Tabel 2. Kriteria Ketuntasan Hasil Belajar

\begin{tabular}{cc}
\hline Rentang Capaian (\%) & Predikat \\
\hline $60-100$ & Tuntas \\
\hline $0-59$ & Tidak Tuntas \\
\hline
\end{tabular}

Sumber: SMPN 13 Manokwari.

untuk mengukur ketuntasan peserta didik secara klasikal menggunakan rumus sebagai berikut:

$$
\text { Keterangan } \mathrm{p}=\frac{f}{N} X 100 \%[8]
$$

$\mathrm{p}=$ presentasi ketuntasan

$f=$ jumlah siswa yang tuntas belajar

$\mathrm{N}=$ jumlah seluruh siswa

\section{HASIL PENELITIAN}

Penelitian ini merupakan Penelitian Tindakan Kelas (PTK) yang dilaksanakan di SMPN 13 Manokwari yang bertujuan untuk meningkatkan kemampuan hasil belajar peserta didik dengan menerapkan model pembelajaran Problem Based Learning (PBL). Penelitian ini dilakukan dalam dua siklus pada masing-masing siklus dilakukan sebanyak dua kali pertemuan sesuai jadwal kegiatan pelajaran. Subjek penelitian ini adalah peserta didik di kelas VIII A yang berjumlah sebanyak 24 peserta didik, terdiri dari 12 peserta didik putra dan 12 peserta didik putri.

Hasil observasi 1 dan observasi 2 pada kegiatan belajar siklus I pertemuan yang dilakukan guru dalam menerapkan model pembelajaran Problem Based Learning (PBL) dapat dilihat pada Tabel 3 berikut ini.

\begin{tabular}{|c|c|c|c|}
\hline \multirow[t]{2}{*}{$\overline{\text { No }}$} & \multirow[t]{2}{*}{ Aspek yang diamati } & \multicolumn{2}{|c|}{ Capaian \% } \\
\hline & & pertemuan 1 & Pertemuan 2 \\
\hline 1 & $\begin{array}{l}\text { Membuka kegiatan pembelajaran dengan mengucapkan } \\
\text { salam dan melakukan absensi kehadiran peserta didik }\end{array}$ & 100 & 100 \\
\hline 2 & Memberi apersepsi & 100 & 83 \\
\hline 3 & $\begin{array}{l}\text { Menyampaikan inti materi dan tujuan pembelajaran yang } \\
\text { ingin dicapai }\end{array}$ & 100 & 100 \\
\hline 4 & Membagi peserta didik secara heterogen dan tertib & 100 & 100 \\
\hline 5 & $\begin{array}{l}\text { Membagi lembar diskusi peserta didik dan menjelaskan cara } \\
\text { kerjanya }\end{array}$ & 100 & 100 \\
\hline 6 & $\begin{array}{l}\text { Meminta peserta didik berdiskusi dalam kelompok dan } \\
\text { membimbing peserta didik dalam diskusi kelompok }\end{array}$ & 100 & 100 \\
\hline 7 & $\begin{array}{l}\text { Memberi peserta didik kesempatan untuk mempresentasikan } \\
\text { hasil diskusi kelompok }\end{array}$ & 100 & 100 \\
\hline 8 & Menanggapi hasil diskusi peserta didik & 83 & 100 \\
\hline 9 & Menyimpulkan hasil pembelajaran & 67 & 83 \\
\hline 10 & Berdoa bersama dan mengucapkan salam & 83 & 100 \\
\hline & Rata-rata & 93,3 & 96,7 \\
\hline
\end{tabular}

Tabel 3. Data Hasil Observasi Kegiatan Guru Siklus I Pertemuan 1 dan 2 
Iwan, Ester L. R. Korwa, dan Hengky L. Wambrauw
Peningkatkan Hasil Belajar Peserta Didik Melalui Penerapan Model Pembelajaran Problem Based Learning pada Materi Sistem Pencernaan Manusia Kelas VIII A SMPN 13 Manokwari
Berdasarkan Tabel 3 yaitu data hasil observasi kegiatan guru pada siklus I pertemuan 1 kegiatan 1-10 mencapai predikat sangat baik $(93,3)$ dan pada siklus I pertemuan 2 dari kegiatan 1-10 mencapai predikat sangat baik $(96,7)$
Lembar observasi kegiatan peserta didik dilakukan 2 kali penilaian untuk setiap siklus. Pada siklus I pertemuan 1dan 2 terdapat 9 aspek yang diamati yaitu dapat dilihat pada Tabel 4.

Tabel 4. Data Hasil Observasi Kegiatan Peserta Didik Siklus I

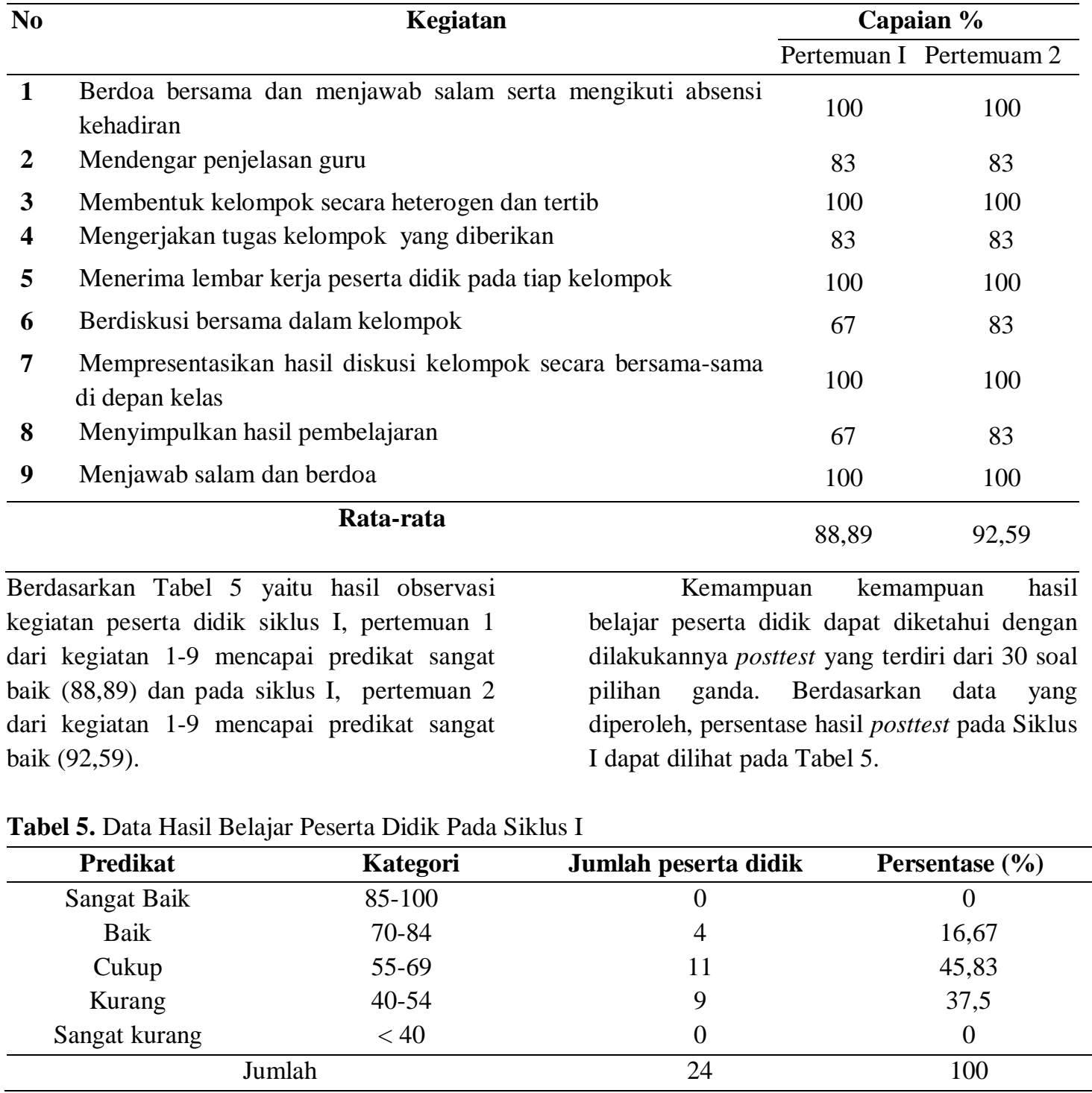


Iwan, Ester L. R. Korwa, dan Hengky L. Wambrauw
Peningkatkan Hasil Belajar Peserta Didik Melalui Penerapan Model Pembelajaran Problem Based Learning pada Materi Sistem Pencernaan Manusia Kelas VIII A SMPN 13 Manokwari

Tabel 6. Ketuntasan Hasil Belajar Siklus I

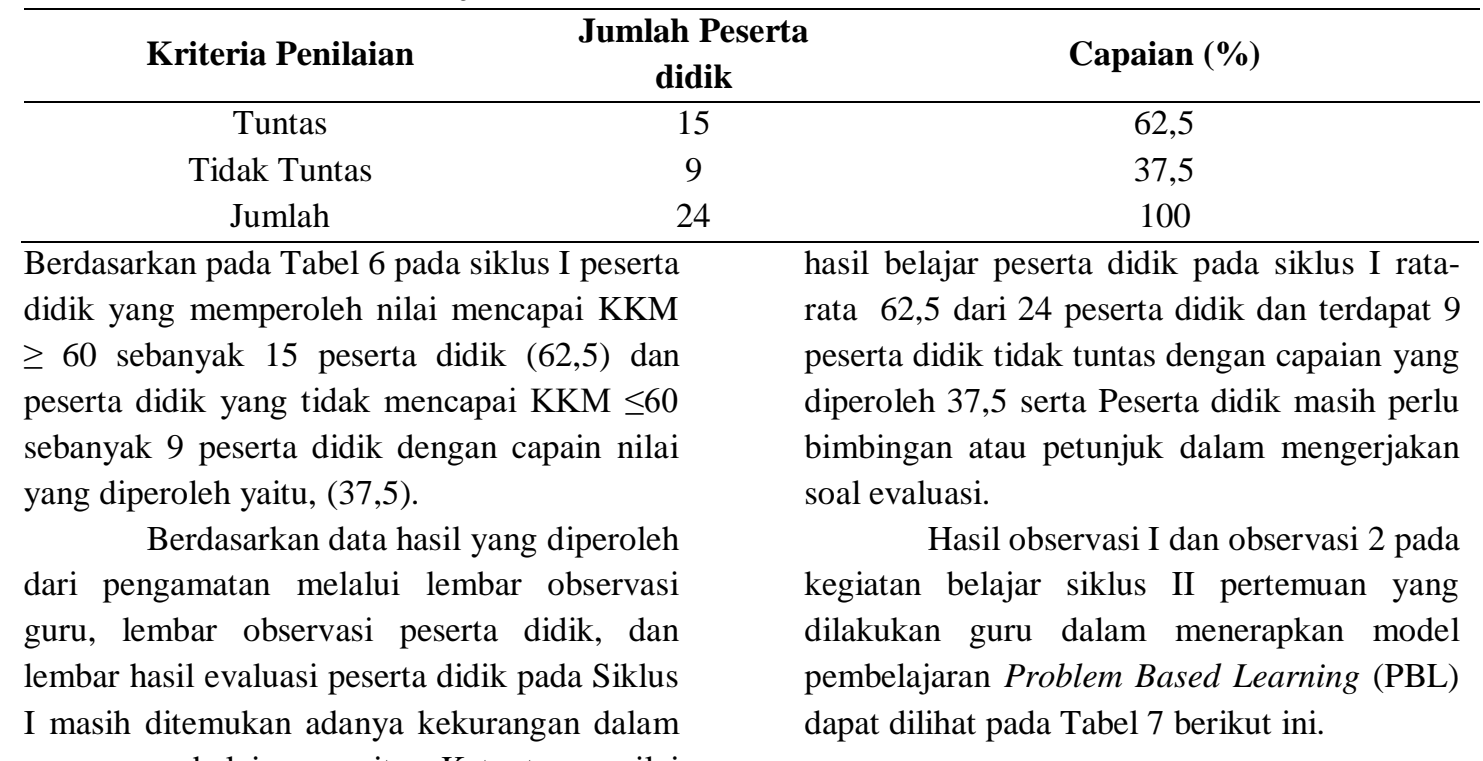

Tabel 7. Data Hasil Observasi Kegiatan Guru Siklus II

\begin{tabular}{|c|c|c|c|}
\hline \multirow[t]{2}{*}{ No } & \multirow[t]{2}{*}{ Aspek yang diamati } & \multicolumn{2}{|c|}{ Capaian \% } \\
\hline & & Pertemuan 1 & Pertemuan 2 \\
\hline 1 & $\begin{array}{l}\text { Membuka kegiatan pembelajaran dengan mengucapkan } \\
\text { salam dan melakukan absensi kehadiran peserta didik }\end{array}$ & 100 & 100 \\
\hline 2 & Memberi apersepsi & 100 & 100 \\
\hline 3 & $\begin{array}{l}\text { Menyampaikan inti materi dan tujuan pembelajaran yang } \\
\text { ingin dicapai }\end{array}$ & 100 & 100 \\
\hline 4 & Membagi peserta didik secara heterogen & 100 & 100 \\
\hline 5 & $\begin{array}{l}\text { Membagi lembar diskusi peserta didik dan } \\
\text { menjelaskan cara kerjanya }\end{array}$ & 100 & 100 \\
\hline 6 & $\begin{array}{l}\text { Meminta peserta didik berdiskusi dalam kelompok dan } \\
\text { membimbing peserta didik dalam diskusi kelompok }\end{array}$ & 100 & 100 \\
\hline 7 & $\begin{array}{l}\text { Memberi peserta didik kesempatan untuk } \\
\text { mempresentasikan hasil diskusi kelompok }\end{array}$ & 100 & 100 \\
\hline 8 & Menanggapi hasil diskusi peserta didik & 100 & 100 \\
\hline 9 & Menyimpulkan hasil pembelajaran & 83 & 83 \\
\hline 10 & Berdoa bersama dan mengucapkan salam & 100 & 100 \\
\hline & Rata-rata & 96,67 & 98,33 \\
\hline
\end{tabular}

kegiatan 1-10 mencapai predikat sangat baik

$(96,67)$ dan pada siklus II pertemuan 2 dari 
Iwan, Ester L. R. Korwa, dan Hengky L. Wambrauw
Peningkatkan Hasil Belajar Peserta Didik Melalui Penerapan Model Pembelajaran Problem Based Learning pada Materi Sistem Pencernaan Manusia Kelas VIII A SMPN 13 Manokwari

Tabel 8. Data Hasil Observasi Kegiatan Peserta Didik Siklus II

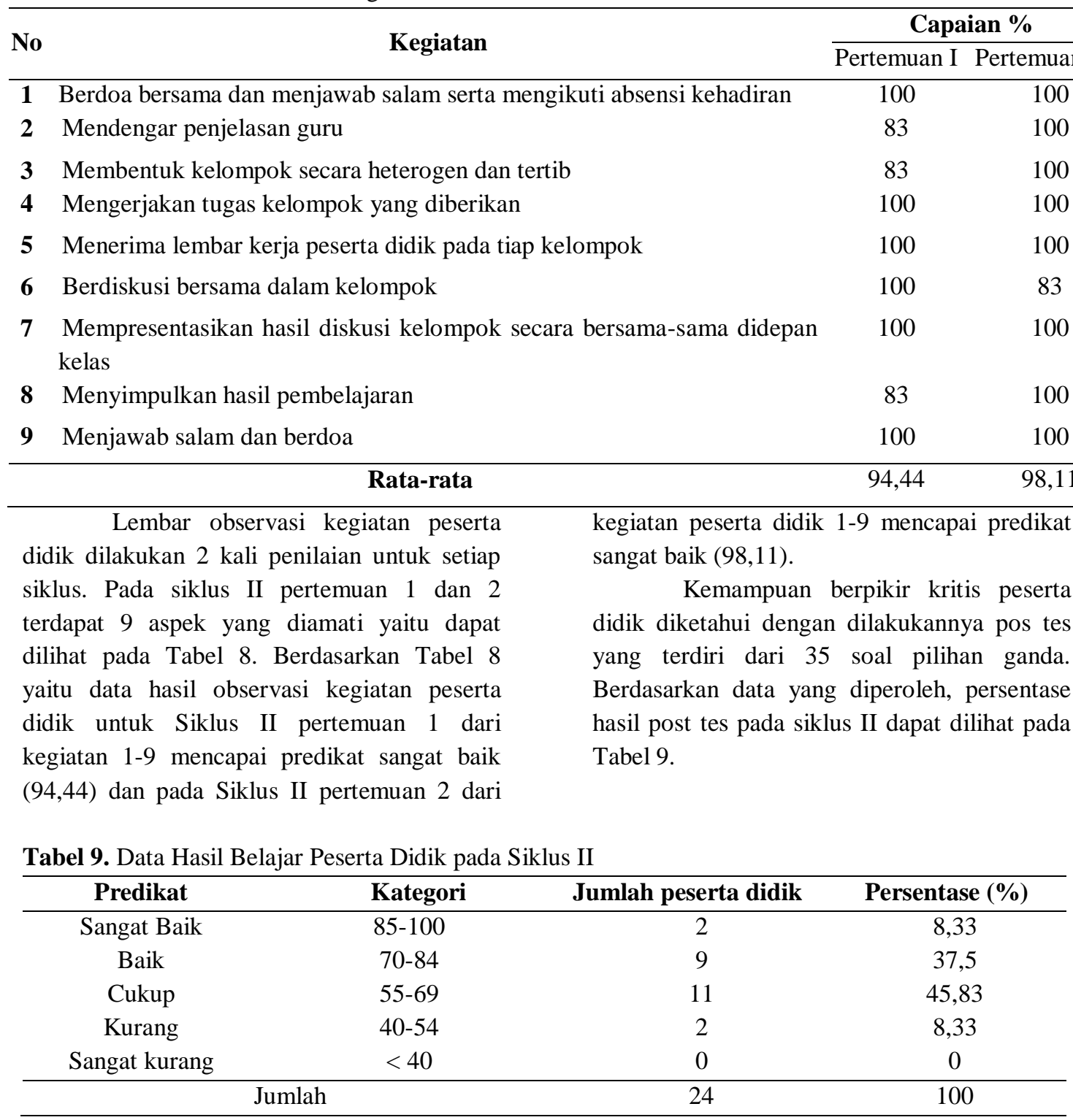

Tabel 10. Ketuntasan Hasil Belajar Siklus II

\begin{tabular}{ccc}
\hline Kriteria Penilaian & $\begin{array}{c}\text { Jumlah Peserta } \\
\text { didik }\end{array}$ & Capaian (\%) \\
Tuntas & 20 & 83,33 \\
Tidak Tuntas & 4 & 16,67 \\
\hline Jumlah & 24 & 100 \\
\hline Berdasarkan pada Tabel 10 pada siklus II & Dan peserta didik yang tidak mencapai KKM \\
peserta didik yang memperoleh nilai mencapai & $\leq 60$ sebanyak 4 peserta didik (16,67). \\
KKM $\geq 60$ sebanyak 20 peserta didik (83,33). & \\
\hline
\end{tabular}


Iwan, Ester L. R. Korwa, dan Hengky L. Wambrauw
Peningkatkan Hasil Belajar Peserta Didik Melalui Penerapan Model Pembelajaran Problem Based Learning pada Materi Sistem Pencernaan Manusia Kelas VIII A SMPN 13 Manokwari
Berdasarkan data hasil yang diperoleh dari pengamatan melalui lembar observasi guru, lembar observasi peserta didik, dan hasil evaluasi peserta didik pada siklus II masih ditemukan adanya kekurangan dalam proses pembelajaran yaitu: Ketuntasan nilai hasil belajar peserta didik pada Siklus II rata-rata 83,33 dari 24 peserta didik dan terdapat 4 peserta didik tidak tuntas dengan capaian yang diperoleh16,67 Dikarenakan keempat peserta didik tersebut tidak mengikuti proses pembelajaran dengan baik. Sehingga hasil yang diperoleh tidak mencapai KKM Sekolah yaitu $\geq 60$ yang di tentukan serta Peserta didik masih perlu bimbingan atau petunjuk dalam mengerjakan soal evaluasi.

Berdasarkan pelaksanaan tindakan dengan menerapkan Model pembelajaran Problem Based Learning (PBL) yang diterapkan pada peserta didik di kelas VIII A SMPN 13 Manokwari diperoleh dari tes evaluasi pada setiap siklus. Nilai rata-rata hasil belajar peserta didik pada siklus I dengan kriteria cukup yaitu mencapai 61,3 dan pada siklus II dengan kriteri baik yaitu mencapai 69,3 . Sedangkan rata-rata presentase hasil belajar peserta didik pada siklus I mencapai $62,5 \%$ dan pada siklus II mencapai $83,35 \%$. Proses pembelajaran aktif yang dilalui peserta didik inilah yang dapat menumbuhkan kreaktivitas mereka, karena pada dasarnya kreaktivitas juga dapat dihasilkan dari kondisi pribadi dan lingkungan individu berperilaku kreaktif [4].

Hasil observasi kegiatan belajar yang dilakukan pada saat proses pembelajaran berlangsung dengan menerapkan model Pembelajaran Problem Based Learning (PBL) meningkat, dapat dilihat pada peserta didik aktif menanggapi permasalahan yang ada, aktif berdiskusi bersama-sama dalam kelompok, aktif mempresentasi di depan kelasdan menjawab. Pada Siklus I dapat menunjukkan bahwa, dalam hal sikap peserta didik saat mengikuti proses pembelajaran sudah baik. Sikap peserta didik merupakan salah satu faktor yang mempengaruhi hasil belajar sehingga, kreaktifitas sangat bermakna dan perlu dikembangkan dalam diri setiap anak didik [9]. Namun pada tingkat pemahaman terhadap materi ada beberapa peserta didik yang masih kesulitan dalam mengerjakan soal tes evaluas dari hasil refleksi pada siklus I, sehingga peneliti perlu melanjutkan ke siklus II untuk memperbaiki hasil yang diperoleh dari siklus I. Pada pelaksanaan Siklus II yang merupakan perbaikan dari tindakan Siklus I memberikan hasil peningkatan yang cukup baik. Setelah melaksanakan tindakan pada siklus II dengan menerapakan model pembelajaran Problem Based Learning (PBL), dengan menggunakan materi sistem pencernaan pada manusia, maka hasil belajar peserta didik mengalami peningkatan mencapai 83,3.

Presentasi nilai hasil belajar peserta didik dapat diamati dari kriteria ketuntasan, yaitu pada siklus I, peserta didik yang mencapai ketuntasan hasil belajar mencapai $62,5 \%$ sedangkan pada siklus II mencapai $83,3 \%$. Hal ini disebabkan karena peserta didik sangat senang belajar dengan menggunakan model pembelajaran Problem Based Learning (PBL) karena model pembelajaran ini memiliki kelebihan yang berbeda dengan model pembelajaran lain yaitu mendorong peserta didik untuk mampu menyelesaikan masalah secara mandiri maupun bekerja sama dalam kelompok, serta memberi tanggung jawab yang sama untuk mencapai tujuan bersama dan semua anggota kelompok harus bekerja sama dengan baik dalam memecahkan masalah yang dihadapi sehingga dapat mencapai hasil yang maksimal. Seperti penelitian yang dilakukan Suharni (2013) model PBL dapat meningkatkan motivasi belajar siswa [9]. 
Iwan, Ester L. R. Korwa, dan Hengky L. Wambrauw
Peningkatkan Hasil Belajar Peserta Didik Melalui Penerapan Model Pembelajaran Problem Based Learning pada Materi Sistem Pencernaan Manusia Kelas VIII A SMPN 13 Manokwari

\section{KESIMPULAN}

Berdasarkan hasil penelitian yang dilakukan pada siklus I dan siklus II maka dapat disimpulkan bahwa Penerapan model pembelajaran Problem Based Learning (PBL) dapat meningkatkan hasil belajar peserta didik, hal ini dapat dilihat dari ketuntasan hasil belajar peserta didik pada siklus I mencapai ketuntasan hasil belajar $63 \%$ dengan rata-rata 61,3 dan nilai pada siklus II yaitu ketuntasan Kasikal mencapai $83 \%$ dengan rata-rata 69,3. Hasil ini dapat didukung dengan kegiatan guru dan kegiatan peserta didik.

\section{DAFTAR PUSTAKA}

[1] BSNP. 2010. Paradigma Pendidikan Nasional Abad XXI. Jakarta: Badan Standar Nasional Pendidikan.

[2] Sudrajat, A. 2008. Lesson Study Untuk Meningkatkan Pembelajaran. (http:// Akhad sudrajat. Wordpress.com (diakses pada 23 juli 2017).

[3] Shomin A. 2014. Model Pembelajaran Inovatif dalam Kurikulum 2013 (ar$R U Z)$. Yogyakarta.

[4] Dayanti E. B, Hasrudin, dan Edi Sahmi. 2016. Pengaruh Model Pembelajaran Berbasis Masalah dan Group Investigation terhadap hasil belajar dan kemampuan berpikir kreatif pada materi sistem pencernaan makanan si
SMA Negeri 1 Muara Batu Kabupaten Aceh Utara. Jurnal pendidikan biologi. Vol 5 (2): 67-73.

[5] Tanujaya. 2016. Metode Penelitian. Surabaya: Penerbit Cahaya Baru.

[6] Baransano, A. 2017. Penerapan Model Pembelajaran Picture and Picture untuk Meningkatkan Aktivitas dan Hasil Belajar Siswa pada Materi Sistem Reproduksi pada Manusia di Kelas XI IPA SMA Kristen Yayasan Anu Beta Tubat (Yabt) Manokwari, Skripsi Mahasiswa Pendidikan Biologi. FKIP UNIPA Manokwari.

[7] Istiqomah dan Sulton M. 2013. Sukses Uji Kompetensi Guru. Penerbit Dunia Cerdas: Malang.

[8] Haqul S, M. 2016. Penerapan Model Pembelajaran Inkuiri untuk Meningkatkan Hasil Belajar IPA Kelas V Sekolah Dasar. Jurnal JPGSD. FIP 04.

[9] Wahyuni, D., dkk. 2015. Efektivitas implementasi pembelajaran model Problem Based Learning (PBL) diintegrasikan dengan PredictObserve-Explain (POE) terhadap prestasi belajar siswa ditinjau dari kreativitas dan kemampuan inferensi siswa. Jurnal inkuiri. FKIP. Vol 4 (1) 47-62. 